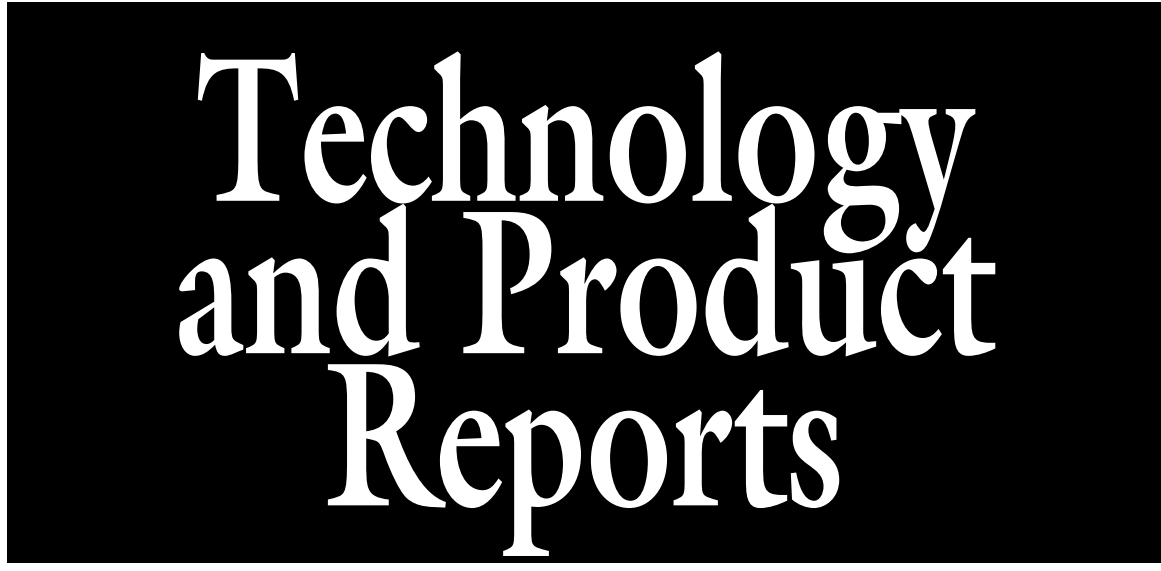

Steaming and Flaming for Converting Cool-season Turfgrasses to Hybrid Bermudagrass in Untilled Soil

\author{
Marco Fontanelli ${ }^{1}$, Michel Pirchio, Christian Frasconi, \\ Luisa Martelloni, Michele Raffaelli, Andrea Peruzzi, Nicola Grossi, \\ Lisa Caturegli, Simone Magni, Monica Gaetani, and \\ Marco Volterrani
}

ADDITIONAL INDEX WORDs. nonchemical turfgrass conversion, conservation tillage, flaming machine, steaming machine, dose-response curves, Festuca arundinacea, Lolium perenne

SumMary. Turfgrass species can be classified into two main groups: cool-season and warm-season species. Warm-season species are more suited to a Mediterranean climate. Transplanting is a possible method to convert a cool-season to a warmseason turfgrass in untilled soil. It generally requires the chemical desiccation of the cool-season turfgrass. However, alternative physical methods, like flaming and steaming, are also available. This paper compares flaming, steaming, and herbicide application to desiccate cool-season turfgrass, for conversion to hybrid bermudagrass (Cynodon dactylon $\mathrm{x}$ C. transvaalensis) in untilled soil, using transplanting. Two prototype machines were used, a self-propelled steaming machine and a tractor-mounted liquefied petroleum gas flaming machine. Treatments compared in this work were two flaming treatments and two steaming treatments performed at four different doses together with two chemical treatments with glufosinateammonium herbicide applications. The cool-season turfgrass species were tall fescue (Festuca arundinacea) and perennial ryegrass (Lolium perenne). The desiccation effect of the various treatments on cool-season turf was assessed by photographic survey 15 days after treatment. The percentage cover of hybrid bermudagrass was visually assessed at 43 weeks after planting. Steaming and flaming effects on both parameters were described by logistic curves. The highest doses of steaming and flaming almost completely desiccated cool-season turf, and similar hybrid bermudagrass cover was established by both the methods as the chemical application ( $50 \%$ to $60 \%$ ). Thus both flaming and steaming may be considered as valid alternatives to herbicides aimed at turf conversion.

$\mathrm{T}$ Uurfgrass species can be classified into two main groups: cool-season and warm-season species. Because of their different physiology, warm-season species need less water to produce the same dry matter weight, thus they are more suited to Mediterranean climates
(Croce et al., 2004; Turgeon, 2012; Volterrani and De Bertoldi, 2012) and have superior wear resistance and recovery compared with coolseason turf species (Lulli et al., 2012).

Transplanting single-potted plants is an innovative technique developed in Italy to convert cool-season to warm- season turfgrasses (Volterrani et al., 2008). Transplanting is based on the quick groundcovering capacity by stolons and rhizomes of small turf plants grown in a nursery garden. Transplanting can be accomplished manually or mechanically, in untilled soil, and is significantly cheaper than sodding. Although transplanting is efficient in converting a cool-season turfgrass to a warm-season turfgrass when soil tillage is not performed, the previous turf has to be completely desiccated.

Desiccation is usually achieved with chemical methods, such as herbicides, and the most common active ingredients are glyphosate and glufosinate ammonium (Baldi et al., 2013; Del Viva, 2012; Volterrani et al., 2008). However, clause 16 of EU Directive 2009/128/CE strongly discourages or prohibits the use of chemical herbicides, such as glyphosate, in public gardens, parks, sport turfs, and schoolyards. As a possible alternative, turfgrass can also be desiccated using flaming and steaming as an alternative to chemical weed control in organic/integrated farming and urban hard surfaces (Bàrberi et al., 2009; Peruzzi et al., 2011, 2012; Raffaelli et al., 2013, 2016).

Weeds and turfgrass species respond differently to physical treatments depending on their particular characteristics. Grasses (Gramineae) are monocots. Monocots have evolved to develop meristems protected by several leaf sheets (Baldoin et al., 2010), whereas dicots usually have all their meristems above the ground and widely over the plant. Grass turf species are less sensitive than most dicots to physical desiccation because they grow back from the protected meristems after the treatment unlike many dicots (Melander et al., 2009; Ulloa et al., 2010a). Rask et al. (2012) found that grass turf species, such as perennial ryegrass, are difficult to control with physical methods because the parts affected are mainly above the ground. Several authors have tested the effects on sensitive species of a single treatment with different flaming doses (Ascard, 1995; Ulloa et al., 2010a, 2010b) and steaming doses (Hansson and Ascard, 2002). However, there is still very little understanding concerning the effects of such techniques on less sensitive species such as grass turf species (Rask et al., 2012). Rask and Kristoffersen (2007) 
suggest that more than one treatment is required to efficiently desiccate grass turf species using flaming and steaming because otherwise they recover. Flaming can also be used as an effective weed control method before turfgrass establishment (Hoyle et al., 2012).

Alternative methods to flaming and steaming have been applied and tested over the years to desiccate vegetation using physical techniques. Hansson and Ascard (2002) experimented with the use of hot water to control weeds growing in hard surfaces. Sartorato et al. (2006) applied microwaves for postemergence weed control. However, flaming is still the most frequently applied physical method to desiccate vegetation. Steaming has been described by various authors as a valid alternative to flaming (Hansson and Ascard, 2002; Kerpauskas et al., 2006) and several agricultural machines for steam application have been developed (Gay et al., 2010a, 2010b; Langshaw, 1995).

The aim of this study was to compare flaming and steaming, performed by dedicated prototype equipment, with a glufosinate-ammonium herbicide treatment to desiccate coolseason turfgrass for conversion to warm-season turfgrass in untilled soil using transplanting.

\section{Materials and methods}

The experimental trial. The trial consisted of desiccating the cool-season turfgrass, using flaming, steaming, and glufosinate-ammoniumbased herbicide (Basta; Bayer AG, Leverkusen, Germany) followed by transplanting the warm-season turfgrass directly into the desiccated turf with no soil tillage. The trial took place in Spring-Summer 2009 at the Department of Agriculture, Food and Environment of the University of Pisa, Italy (lat. $43^{\circ} 40^{\prime} \mathrm{N}$, long. $\left.10^{\circ} 18^{\prime} \mathrm{E}\right)$. The trial was performed on 4-year-old turf established on siltloam soil $(28 \%$ sand, $55 \%$ silt, and $17 \%$ clay) with a $\mathrm{pH}$ of 7.6 and $25 \mathrm{~g} \cdot \mathrm{kg}^{-1}$ organic matter.

The cool-season turfgrass species were 'Eldorado' and 'Barfelix' tall

Department of Agriculture, Food and Environment (DAFE), University of Pisa, 56124 Pisa, Italy

${ }^{1}$ Corresponding author. E-mail: marco.fontanelli@ unipi.it.

doi: 10.21273/HORTTECH03773-17 fescue and 'Barsportivo' and 'Brightstar' perennial ryegrass. Broadcast fertilization of the cool-season turf was conducted from Nov. 2008 to Apr. 2009 for a total of $150 \mathrm{~kg} \cdot \mathrm{ha}^{-1}$ of nitrogen $(\mathrm{N})$ using ammonium sulfate $[20.6 \mathrm{~N}-0 \mathrm{P}-0 \mathrm{~K}$ (Pratiko; Adriatica, Loreo, Italy)]. Cool-season turf height was maintained at $3.5 \mathrm{~cm}$ with a rotary mower. Irrigation was applied to maintain a healthy cool-season turf. No aerification or pest control was carried out during the trial.

The treatments performed (11 and 25 June 2009) and compared were, two flaming treatments performed at a constant liquefied petroleum gas (LPG) working pressure of $0.3 \mathrm{MPa}$. Flaming was performed at four different working speeds with four different LPG doses (Table 1); two steaming treatments performed with four different values of working speed obtaining four different steam doses (Table 1); two glufosinateammonium herbicide applications at $0.75 \mathrm{~kg} \cdot \mathrm{ha}^{-1}$ a.i., and no treatments (control plots).

Turf conversion was accomplished by transplanting hybrid bermudagrass directly into the desiccated cool-season turf with no soil tillage. Single plants of 'Patriot' hybrid bermudagrass were used for the transplant. The transplant was carried out manually on 3 July 2009 with a square transplant pattern with $30 \mathrm{~cm}$ between plants (with a transplant density of 11.1 plants $\left./ \mathrm{m}^{2}\right)$. This transplanting density is ideal for hybrid bermudagrass, based on the quick groundcovering capacity of this plant, and comes from previous research (Volterrani et al., 2008).
Hybrid bermudagrass plants were obtained from sprigs and raised in peat-filled nursery trays (peat volume available for each plant was $5 \mathrm{~cm}^{3}$ ). At the time of transplant, plants were $6-10 \mathrm{~cm}$ in height and had not been trimmed. Irrigation after the transplant ( $5 \mathrm{~mm}$ per application) was carried out daily until the end of September. Nitrogen application after transplant was carried out on 10 and 20 July with urea [46N-0P-0K (Urea 46\% Prilled; Fertilsud, Spinazzola, Italy)] for a total $\mathrm{N}$ rate of $100 \mathrm{~kg} \cdot \mathrm{ha}^{-1}$. The first mowing of the hybrid bermudagrass took place on 30 July with a reel mower set at $3-\mathrm{cm}$ mowing height. Mowing was then performed weekly at $2.5 \mathrm{~cm}$. No aerification or pest control was carried out during the trial.

DESCRIPTION OF THE MACHINES. A self-propelled steaming machine and a tractor-mounted flaming machine were used to perform coolseason turf desiccation. Chemical cool-season turf desiccation was performed with a pushed wheelbarrow sprayer with a frontal 1-m-wide boom, flat fan nozzles, 2 bars pressure, $3 \mathrm{~km} \cdot \mathrm{h}^{-1}$ speed, and $300 \mathrm{~L} \cdot \mathrm{ha}^{-1}$ total mixture volume.

Steaming machine. A selfpropelled steaming machine (Ecostar SC 600; Celli, Forli, Italy) designed to be a soil disinfection machine that delivers steam underground (Peruzzi et al., 2011) was used. In this trial it was modified to deliver steam aboveground level and not underground, to desiccate the vegetation (Fig. 1). The machine was $4 \mathrm{~m}$ long, $2 \mathrm{~m}$ wide, $1.5 \mathrm{~m}$ high, and weighed $\approx 3000 \mathrm{~kg}$. It was equipped with rubber tracks to enhance maneuverability and reduce

\begin{tabular}{|c|c|c|c|}
\hline \multicolumn{4}{|l|}{ Units } \\
\hline $\begin{array}{l}\text { To convert U.S. to SI, } \\
\text { multiply by }\end{array}$ & U.S. unit & SI unit & $\begin{array}{l}\text { To convert SI to U.S., } \\
\text { multiply by }\end{array}$ \\
\hline 0.4047 & $\operatorname{acre}(\mathrm{s})$ & ha & 2.4711 \\
\hline 100 & bar & $\mathrm{kPa}$ & 0.01 \\
\hline 0.0011 & Btu & MJ & 947.8171 \\
\hline 0.3048 & $\mathrm{ft}$ & $\mathrm{m}$ & 3.2808 \\
\hline 0.0929 & $\mathrm{ft}^{2}$ & $\mathrm{~m}^{2}$ & 10.7639 \\
\hline 9.3540 & $\mathrm{gal} / \mathrm{acre}$ & $\mathrm{L} \cdot \mathrm{ha}^{-1}$ & 0.1069 \\
\hline 0.7457 & horsepower & $\mathrm{kW}$ & 1.3410 \\
\hline 2.54 & inch(es) & $\mathrm{cm}$ & 0.3937 \\
\hline 25.4 & inch(es) & $\mathrm{mm}$ & 0.0394 \\
\hline 16.3871 & inch $^{3}$ & $\mathrm{~cm}^{3}$ & 0.0610 \\
\hline 0.4536 & $\mathrm{lb}$ & $\mathrm{kg}$ & 2.2046 \\
\hline 1.1209 & $\mathrm{lb} /$ acre & $\mathrm{kg} \cdot \mathrm{ha}^{-1}$ & 0.8922 \\
\hline 1.6093 & $\mathrm{mph}$ & $\mathrm{km} \cdot \mathrm{h}^{-1}$ & 0.6214 \\
\hline 7.4892 & $\mathrm{oz} / \mathrm{gal}$ & $\mathrm{g} \cdot \mathrm{L}^{-1}$ & 0.1335 \\
\hline 62.5000 & $\mathrm{oz} / \mathrm{lb}$ & $\mathrm{g} \cdot \mathrm{kg}^{-1}$ & 0.0160 \\
\hline 0.0069 & psí & $\mathrm{MPa}$ & 145.0377 \\
\hline
\end{tabular}


soil compaction. The power train delivered $44 \mathrm{~kW}$ of maximum power. The machine was equipped with both a steam generation and steam application system. The steam generation system consisted of a diesel steam

Table 1. Different working speeds and liquefied petroleum gas (LPG) and steam doses for the two prototypes used for physical desiccation of cool-season turfgrass before the conversion to warmseason turfgrass.

\begin{tabular}{lc}
\hline $\begin{array}{l}\text { Working speed } \\
\left(\mathbf{k m} \cdot \mathbf{h}^{-\mathbf{1}}\right)^{\mathbf{z}}\end{array}$ & $\begin{array}{c}\text { LPG doses } \\
\left(\mathbf{k g} \cdot \mathbf{h a}^{-\mathbf{l}}\right)^{\mathbf{z}}\end{array}$ \\
\hline 4 & 35 \\
2 & 70 \\
1 & 140 \\
0.5 & 280
\end{tabular}

\begin{tabular}{cc}
\hline $\begin{array}{l}\text { Working speed } \\
\left(\mathbf{k m} \cdot \mathrm{h}^{-1}\right)\end{array}$ & $\begin{array}{c}\text { Steam doses } \\
\left(\mathrm{kg} \cdot \mathrm{ha}^{-1}\right)\end{array}$ \\
\hline 0.25 & 12,000 \\
0.50 & 6,000 \\
0.75 & 4,000 \\
1.50 & 2,000 \\
\hline${ }^{\mathrm{z}} 1 \mathrm{~km} \cdot \mathrm{h}^{-1}=0.6214 \mathrm{mph}, 1 \mathrm{~kg} \cdot \mathrm{ha}^{-1}=0.8922 \mathrm{lb} /$ acre.
\end{tabular}

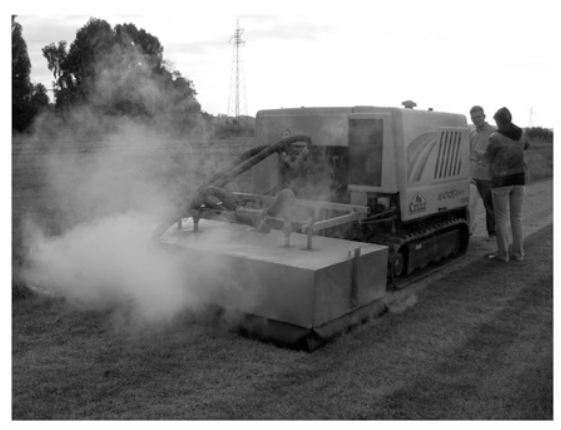

Fig. 1. Steaming machine during a treatment for cool-season turf control. generator with a power of 1507 $\mathrm{MJ} \cdot \mathrm{h}^{-1}$ providing a steam outflow of about $600 \mathrm{~kg} \cdot \mathrm{h}^{-1}$. The steam application system worked by creating a condensation chamber by covering a steaming bar with a carter (a metal "box" completely covering the steaming bar). The carter and the bar were made of stainless steel. The bar was drilled and threaded to enable interchangeable nozzles to be used for flow regulation and for maintenance and replacement. The bar was perpendicular to the driving direction. The steam flow was fed by two hoses connected to the ends of the bar. The carter was $1 \mathrm{~m}$ long, $2 \mathrm{~m}$ wide, and $0.55 \mathrm{~m}$ high. The last $20 \mathrm{~cm}$ of the carter (i.e., the part that can come into contact with the ground) was made of flexible heatproof rubber. The bar was attached to the three-point linkage of the machine and the carter was attached to the bar. The height of the carter was adjustable in relation to the height of the bar. The operating characteristics of the steaming machine are shown in Table 2.

MOUNTED FLAMING MACHINE. The mounted flaming machine was designed to be coupled to a common tractor by a three-point hitch (Raffaelli et al., 2013). The burners can be adjusted by varying their height and inclination with respect to the soil surface (Fig. 2). The set height was maintained by means of articulated parallelograms (a sort of articulated metal frame which allows the burner to follow the soil profile). The flaming machine was equipped with four commercial LPG tanks (both 15 and $25 \mathrm{~kg}$ ), each with a pressure regulator and a manometer. The tanks were connected to a control system. The gas flow regulator valves were electronically controlled by a specific panel. The panel was placed in the tractor's driving cabin.

During the trial, the open flame burners were set at a height of $10 \mathrm{~cm}$ with an angle of $45^{\circ}$ to the ground. The LPG pressure was $0.3 \mathrm{MPa}$. These settings guaranteed an effective flame for ground treatments (welldefined and controllable flame without reflections). In the trial, the machine was equipped with eight 25 -cm-wide prismatic burners (Raffaelli et al., 2015). The effective working width was $2 \mathrm{~m}$.

The operating characteristics of the flaming machine are shown in Table 3.

EXPERIMENTAL FIELD AND DATA COLLeCtion. The experimental field was set up in randomized complete block and 10 different treatments (four steam doses, four LPG doses, one active ingredient, one nontreated control plot) were applied to each species. The plots were $2 \mathrm{~m}$ wide $x$ $10 \mathrm{~m}$ long with four replications.

The effects of the various treatments on cool-season turf desiccation were assessed by photographic survey at $15 \mathrm{~d}$ after treatment (DAT). Subsequent image analysis was performed using Imaging Crop Response Analyser software (Rasmussen et al., 2007) to establish the desiccation percentage of the various treatments. Cover percentage of hybrid bermudagrass after transplant was visually assessed at 43 weeks after planting (WAP).

The LPG dose per hectare was calculated from the LPG hourly consumption measured during test bench trials, as described in Raffaelli et al. (2015). Steam dose per ha was calculated from the hourly steam generator

Table 2. Operating characteristics of the steaming machine prototype used for physical desiccation of cool-season turfgrass before the conversion to warm-season turfgrass.

\begin{tabular}{|c|c|c|c|c|c|}
\hline \multirow{2}{*}{$\begin{array}{l}\text { Operating characteristics } \\
\text { Driving speed }\end{array}$} & \multirow{2}{*}{$\frac{\text { Unit }^{z}}{\mathrm{~m} \cdot \mathrm{h}^{-1}}$} & \multicolumn{4}{|c|}{ Values } \\
\hline & & 250 & 500 & 750 & 1,500 \\
\hline Working width & $\mathrm{m}$ & & & & \\
\hline Effective time & $h \cdot h a^{-1}$ & 20.00 & 10.00 & 6.67 & 3.33 \\
\hline Additional time & $h \cdot h a^{-1}$ & 5.12 & 2.62 & 1.78 & 0.95 \\
\hline Total time & $\mathrm{h} \cdot \mathrm{ha} \mathrm{a}^{-1}$ & 25.12 & 12.62 & 8.46 & 4.29 \\
\hline Work chain efficiency & $\%$ & 79.6 & 79.2 & 78.8 & 77.7 \\
\hline Working productivity & $\mathrm{m}^{2} \cdot \mathrm{h}^{-1}$ & 398 & 792 & 1,182 & 2,331 \\
\hline Machine fuel consumption & $\mathrm{kg} \cdot \mathrm{ha}^{-1}$ & 217 & 108 & 72 & 36 \\
\hline Steam boiler fuel consumption & $\mathrm{kg} \cdot \mathrm{ha}^{-1}$ & 883 & 442 & 295 & 147 \\
\hline Total fuel consumption & $\mathrm{kg} \cdot \mathrm{ha}^{-1}$ & 1,100 & 550 & 367 & 183 \\
\hline Steam boiler water consumption & $\mathrm{kg} \cdot \mathrm{ha}^{-1}$ & 12,000 & 6,000 & 4,000 & 2,000 \\
\hline
\end{tabular}

${ }^{\mathrm{z}} \mathrm{l} \mathrm{m}=3.2808 \mathrm{ft}, \mathrm{l} \mathrm{h} \cdot \mathrm{ha}^{-1}=0.4047 \mathrm{~h} /$ acre, $\mathrm{l} \mathrm{kg} \cdot \mathrm{ha}^{-1}=0.8922 \mathrm{lb} /$ acre, $1 \mathrm{~m}^{2}=10.7639 \mathrm{ft}^{2}$. 
flow $\left(600 \mathrm{~kg} \cdot \mathrm{h}^{-1}\right)$ as reported in Peruzzi et al. (2011).

Statistical analysis. The responses to flaming and steaming treatments were analyzed using a loglogistic model. The extension package drc [dose-response curves (Ritz et al., 2015)] of R (R Core Team, 2016) was chosen to fit nonlinear regressions, estimate their parameter values, and plot the graphs. Residual cool-season turfgrass and hybrid bermudagrass cover data were analyzed using the four parameter log-logistic model (Knezevic et al., 2007; Seefeldt et al., 1995):

$\Upsilon=C+\frac{D-C}{1+\exp \left[B\left(\log X-\log \mathrm{ED}_{50}\right)\right]}$

where $(\Upsilon)$ is the response, $(C)$ is the lower limit, $(D)$ is the upper limit, $(B)$ is the slope of the line at the inflection point, $(X)$ is the LPG or steam dose, and effective dose 50 $\left(\mathrm{ED}_{50}\right)$ is the dose giving a $50 \%$ response between the upper and the lower limits (also known as the inflection point or $\mathrm{ED}_{50}$ ) (Seefeldt et al., 1995). The model fit data were

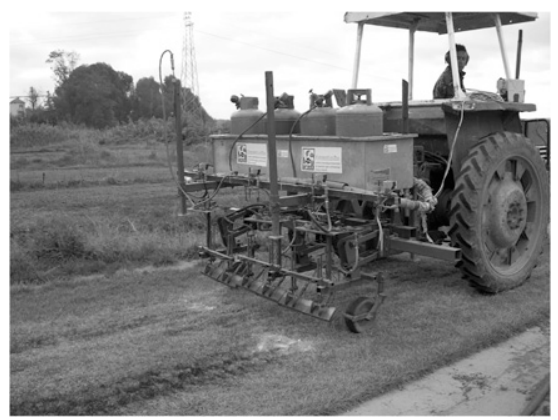

Fig. 2. Flaming machine during a treatment for cool-season turf control. tested using the lack of fit test (if $P>$ 0.05 the model fits well).

The LPG and steaming treatments were then compared with the herbicide using a linear mixed model analysis of variance (ANOVA) and statistical software $\mathrm{R}$ with the extension package lmerTest (Kutznetsova et al., 2015). Data were logit transformed using R extension package car (Fox and Weisberg, 2011). The extension package lsmeans [least-square means (Lenth, 2016)] from R (R Core Team, 2016) was adopted to compare mean values (Wheeler et al., 2005).

\section{Results}

COOL-SEASON TURF DESICCATION. Tall fescue and perennial ryegrass proved to be sensitive to flaming treatments with increasing damage as the LPG dose increased. Tall fescue and perennial ryegrass had an initial cover percentage of $\approx 57 \%$ and $53 \%$, respectively. The mean values of the lower limits of the curves were close to 0 (Fig. 3). The two highest LPG doses on both tall fescue and perennial ryegrass gave mean values of residual turf cover that almost reached the lower limit. $\mathrm{ED}_{50}$ mean values for tall fescue and perennial ryegrass were 35 and $27 \mathrm{~kg} \cdot \mathrm{ha}^{-1}$ of LPG, respectively (Table 4 ).

Tall fescue and perennial ryegrass also proved to be sensitive to steaming treatments, with increasing damage as the steam dose increased. The mean values of the upper limits for both tall fescue and perennial ryegrass were the same as for the flaming treatments. The mean values of the lower limits of the curves were very close to 0 because turf desiccation was close to $100 \%$ where the three highest steam doses had been applied (Fig. 4). ED 50 mean values of steaming on tall fescue and perennial ryegrass were 1216 and 1355 $\mathrm{kg} \cdot \mathrm{ha}^{-1}$ of steam, respectively (Table 5).

Statistical differences were observed between tall fescue and perennial ryegrass turf cover after flaming and herbicide treatments based on comparison of residual lsmeans (Table 6). The two highest LPG doses desiccated tall fescue and perennial ryegrass almost completely (the residual cover was about $2 \%$ and $1 \%$ respectively, which is a relevant result, $98 \%$ to $99 \%$ of control). After the herbicide application, tall fescue and perennial ryegrass were desiccated close to $100 \%$. Tall fescue and perennial ryegrass seemed to be significantly more sensitive to the herbicide than to high LPG doses despite the mean values of residual turf cover being quite similar.

Statistical differences were observed between tall fescue and perennial ryegrass turf cover after steaming and herbicide treatments based on comparison of residual lsmeans ( $\mathrm{Ta}-$ ble 6). The three highest steam doses desiccated tall fescue almost completely (residual cover was $\approx 1 \%$ and $0 \%$, respectively). Tall fescue seemed to be significantly more sensitive to the herbicide than to the high steam doses despite very close residual turf mean values. A similar trend was also observed for the other turf species.

HYBRID BERMUdAgRASS TURF ESTABLISHMENT. There was no significant interaction between LPG, steam doses, and turf species from ANOVA, thus the data were pooled over cool-season turf species. Hybrid bermudagrass establishment proved to be sensitive to flaming treatments applied to the cool-season turfgrass because the percentage of bermudagrass cover increased with increasing

Table 3. Operating characteristics of the flaming machine prototype used for physical desiccation of cool-season turfgrass before the convertion to warm-season turfgrass.

\begin{tabular}{|c|c|c|c|c|c|}
\hline \multirow{2}{*}{$\begin{array}{l}\text { Operating characteristics } \\
\text { Driving speed }\end{array}$} & \multirow{2}{*}{$\frac{\text { Unit }^{\mathbf{z}}}{\mathrm{km} \cdot \mathrm{h}^{-1}}$} & \multicolumn{4}{|c|}{ Values } \\
\hline & & 0.5 & 1 & 2 & 4 \\
\hline Working width & $\mathrm{m}$ & \multicolumn{4}{|c|}{2} \\
\hline Effective time & $\mathrm{h} \cdot \mathrm{ha}^{-1}$ & 10.00 & 5.00 & 2.50 & 1.25 \\
\hline Additional time & $h \cdot h a^{-1}$ & 0.95 & 0.56 & 0.37 & 0.27 \\
\hline Total time & $h \cdot h a^{-1}$ & 10.95 & 5.56 & 2.87 & 1.52 \\
\hline Work chain efficiency & $\%$ & 91.3 & 89.9 & 87.1 & 82.1 \\
\hline Diesel fuel consumption & $\mathrm{kg} \cdot \mathrm{ha}^{-1}$ & 25.5 & 13.0 & 6.7 & 3.5 \\
\hline
\end{tabular}

${ }^{\mathrm{z}} 1 \mathrm{~km} \cdot \mathrm{h}^{-1}=0.6214 \mathrm{mph}, 1 \mathrm{~m}=3.2808 \mathrm{ft}, \mathrm{l} \mathrm{h} \cdot \mathrm{ha}^{-1}=0.4047 \mathrm{~h} /$ acre, $1 \mathrm{~m}^{2}=10.7639 \mathrm{ft}^{2}, \mathrm{l} \mathrm{kg} \cdot \mathrm{ha}^{-1}=0.8922 \mathrm{lb} / \mathrm{acre}$. 
LPG doses (Fig. 5). The mean value of the lower limit of the curve was close to $20 \%$ and was reached on the control plot. The percentage of hybrid bermudagrass cover ranged from $\approx 40 \%$ to $50 \%$ when the three highest LPG doses were applied. The $\mathrm{ED}_{50}$ mean value was $52 \mathrm{~kg} \cdot \mathrm{ha}^{-1}$ of LPG.

Hybrid bermudagrass establishment also proved to be positively affected by steaming treatments applied to the cool-season turfgrass as mean values of hybrid bermudagrass cover increased with increasing steam doses (Fig. 6). The percentage of hybrid bermudagrass cover was $\approx 20 \%$ on the control plot. When the three highest steam doses were applied, mean percentage values of hybrid bermudagrass cover ranged about from $45 \%$ to $>65 \%$. The $\mathrm{ED}_{50}$ mean value was $3537 \mathrm{~kg} \cdot \mathrm{ha}^{-1}$ of steam. Again values can vary considerably because of high standard errors due to field variability.

No statistical differences were observed on hybrid bermudagrass cover, 43 weeks after flaming and herbicide treatments in tall fescue, based on comparison of residual lsmeans ( $\mathrm{Ta}-$ ble 7). Hybrid bermudagrass establishment was over $60 \%$ where herbicide had been applied to desiccate the cool-season turf. The control was the only treatment that gave a significantly lower percentage $(15 \%)$ of hybrid bermudagrass cover with respect to glufosinate ammonium. The four LPG doses did not show a statistical difference from the herbicide (hybrid bermudagrass cover ranged from $45 \%$ to $55 \%$ ).

Statistical differences were observed on hybrid bermudagrass cover after flaming (control and dose $\mathbf{3 4 . 7 5}$ $\mathrm{kg} \cdot \mathrm{ha}^{-1}$ ) and herbicide treatments in perennial ryegrass, based on comparison of residual lsmeans (Table 7). Hybrid bermudagrass cover was $44 \%$ where the herbicide had been applied. Control and LPG dose $35 \mathrm{~kg} \cdot \mathrm{ha}^{-1}$ gave lower hybrid bermudagrass cover percentages $(\approx 17 \%$ and $18 \%$, respectively). There was no statistical different between the three higher LPG doses and the herbicide. Hybrid bermudagrass cover ranged from $\approx 30 \%$ to $>40 \%$ for the three higher LPG doses.

When comparing the steaming treatments with the herbicide, a similar trend was observed. However, hybrid bermudagrass cover reached $70 \%$ with the steaming treatment (Table 7).

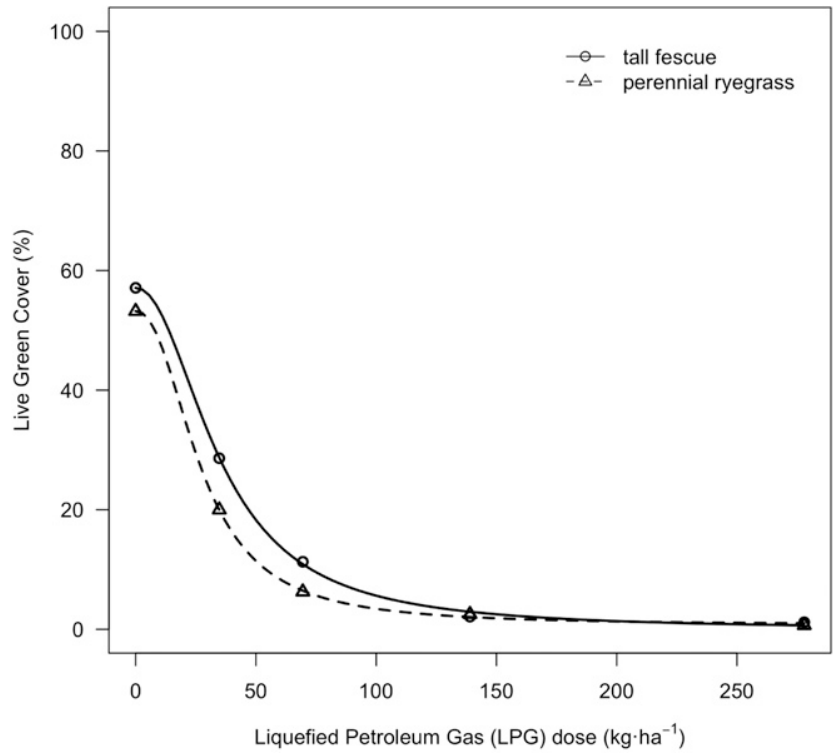

Fig. 3. Influence of flame weeding on cool-season turf cover $15 \mathrm{~d}$ after treatment, as affected by liquefied petroleum gas (LPG) dose. The regression lines are plotted using Eq. $[1]$, and the parameters are presented in Table $4 ; 1 \mathrm{~kg} \cdot \mathrm{ha}^{-1}=0.8922 \mathrm{lb} /$ acre.

Table 4. Regression parameters for cool-season turf cover (\%) $15 \mathrm{~d}$ after treatment as affected by liquefied petroleum gas dose [ $\mathrm{kg} \cdot \mathrm{ha}^{-1}$ (Fig. 3)]. Regression parameters were estimated using Eq. [1].

\begin{tabular}{lcrcc}
\hline & \multicolumn{4}{c}{ Regression parameters $(\mathrm{SE})^{\mathrm{z}}$} \\
\cline { 2 - 5 } Species & $\boldsymbol{B}$ & $\boldsymbol{C}$ & $\boldsymbol{D}$ & ED $_{50}$ \\
\hline Tall fescue & $2.10(0.13)$ & $-0.08(0.63)$ & $57.08(0.56)$ & $34.99(0.77)$ \\
Perennial ryegrass & $2.24(0.23)$ & $0.71(0.59)$ & $53.20(0.56)$ & $27.21(0.90)$ \\
\hline
\end{tabular}

${ }^{\mathrm{z}} B=$ slope of the line at the inflection point, $C=$ lower limit, $D=$ upper limit, $\mathrm{ED}_{50}=$ dose giving a $50 \%$ response between the upper and the lower limit; lack of fit test $P=0.0911$.

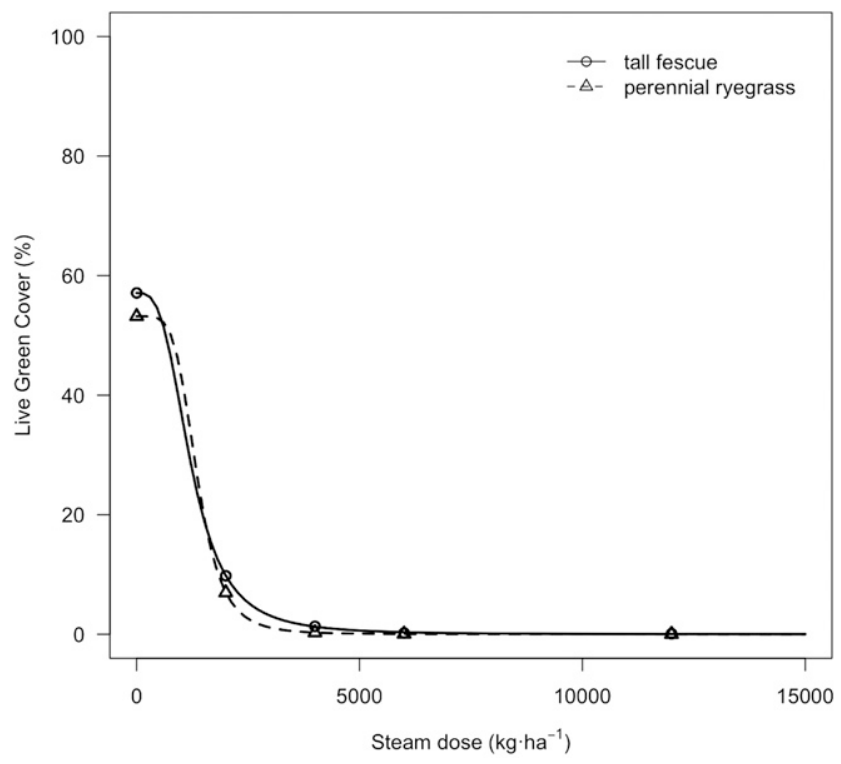

Fig. 4. Influence of steaming on cool-season turf cover $15 \mathrm{~d}$ after treatment, as affected by steam dose. The regression lines are plotted using Eq. [1], and the parameters are presented in Table $5 ; 1 \mathrm{~kg} \cdot \mathrm{ha}^{-1}=0.8922 \mathrm{lb} /$ acre. 
Table 5. Regression parameters for cool-season turf cover (\%) $15 \mathrm{~d}$ after treatment as affected by steam dose [kg.ha-1 $\left(\mathrm{Fig}^{-4}\right)$ ]. Regression parameters were estimated using Eq. [1].

\begin{tabular}{|c|c|c|c|c|}
\hline \multirow[b]{2}{*}{ Species } & \multicolumn{4}{|c|}{ Regression parameters $(S E)^{\mathrm{z}}$} \\
\hline & $B$ & $C$ & $D$ & $\mathrm{ED}_{50}$ \\
\hline Tall fescue & $3.16(0.49)$ & $-0.005(0.291)$ & $57.10(0.31)$ & $1,216(88)$ \\
\hline Perennial ryegrass & $4.86(2.17)$ & $0.03(0.25)$ & $53.20(0.31)$ & $1,355(230)$ \\
\hline
\end{tabular}

${ }^{\mathrm{z}} B=$ slope of the line at the inflection point, $C=$ lower limit, $D=$ upper limit, $\mathrm{ED}_{50}=$ dose giving a $50 \%$ response between the upper and the lower limit; lack of fit test $P=0.8742$.

Table 6. Least-square means of residual cool-season turf cover percentage $15 \mathrm{~d}$ after treatment, before hybrid bermudagrass transplanting, as affected by liquefied petroleum gas dose and steam dose, and comparison with herbicide.

\begin{tabular}{|c|c|c|c|c|c|}
\hline \multirow[b]{2}{*}{ Treatments } & \multirow[b]{2}{*}{ Dose $\left(\mathrm{kg} \cdot \mathrm{ha}^{-1}\right)^{\mathrm{z}}$} & \multicolumn{2}{|c|}{ Tall fescue } & \multicolumn{2}{|c|}{ Perennial ryegrass } \\
\hline & & $\begin{array}{c}\text { Logit transformed } \\
\text { LGC }^{y}(\mathrm{SE})\end{array}$ & $\begin{array}{c}\text { Back transformed } \\
\text { LGC (\%) }\end{array}$ & $\begin{array}{c}\text { Logit transformed } \\
\text { LGC (SE) }\end{array}$ & $\begin{array}{c}\text { Back } \\
\text { transformed LGC (\%) }\end{array}$ \\
\hline Control & 0 & $0.29(0.195)^{*}$ & 57.2 & $0.13(0.088)^{*}$ & 53.2 \\
\hline \multirow[t]{3}{*}{ Flaming } & 35 & $-0.92\left(0.195^{*}\right.$ & 23.1 & $-1.39(0.088)^{*}$ & 17.9 \\
\hline & 70 & $-2.07(0.195)^{*}$ & 8.7 & $-2.71(0.088)^{*}$ & 5.5 \\
\hline & 140 & $-3.85(0.195)^{*}$ & 1.6 & $-3.68(0.088)^{*}$ & 2.2 \\
\hline & 4,000 & $-4.30(0.192)^{*}$ & 1.34 & $-5.80(0.069)^{*}$ & 0.3 \\
\hline & 6,000 & $-6.08(0.192)^{*}$ & 0.23 & $-7.32(0.069)^{*}$ & 0.07 \\
\hline & 12,000 & $-6.75(0.192)^{*}$ & 0.12 & $-7.99(0.069) *$ & 0.03 \\
\hline Glufosinate ammonium & 0.75 & $-7.78(0.195)$ & 0.04 & $-6.43(0.088)$ & 0.16 \\
\hline
\end{tabular}

${ }^{\mathrm{z}} 1 \mathrm{~kg} \cdot \mathrm{ha}^{-1}=0.8922 \mathrm{lb} /$ acre

${ }^{\mathrm{y}}$ Live green cover.

* Significantly different from glufosinate ammonium at $P<0.05$.

\section{Discussion}

The mean values of percentage residual cool-season turf cover at 15 DAT in this trial were overall quite close. Flaming and steaming at high LPG doses seemed to be nearly as effective as the herbicide in desiccating both tall fescue and perennial ryegrass. Steaming gave lower coolseason cover residuals. The regression parameter " $B$ " values in Table 6 (steaming) are higher than those in Table 5 (flaming). Higher values indicate a more sloping curve, thus turfgrass may well be more sensitive to steaming treatments than to flaming treatments even at intermediate doses.

These results suggest that steaming is more efficient than flaming in desiccating grass plants that protected meristems. Syrvidas et al. (2002) state that steaming is more efficient than flaming in desiccating vegetation. Tall fescue and perennial ryegrass are two bunch-type species with meristems located in the grass crown immediately above the ground. Baldoin et al. (2010) tested the effects of a single steaming treatment on three grass species at various growth stages. All species were efficiently desiccated

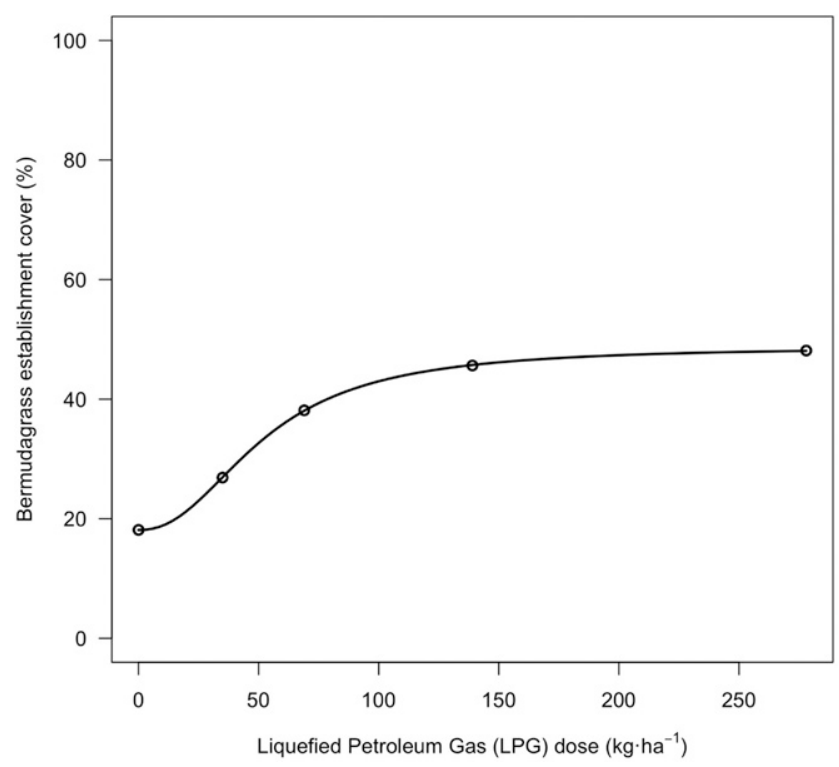

Fig. 5. Influence of preplanting flame weeding on hybrid bermudagrass establishment 43 weeks after planting, as affected by liquefied petroleum gas (LPG) dose. The regression line is plotted using Eq. [1]. Regression parameter values $( \pm \mathrm{SE})$ are: $B=-2.25 \pm 1.90, C=18.11 \pm 5.51, D=48.77 \pm 6.82, \mathrm{ED}_{50}=$ $52.34 \pm 21.05$; lack of fit test $P=0.9812 ; 1 \mathrm{~kg} \cdot \mathrm{ha}^{-1}=0.8922 \mathrm{lb} / \mathrm{acre}$.

even at low steam doses but some recovery after the treatment was observed depending on the growth stage. Smaller plants probably offer less protection to their meristems, and if the crown is damaged, the chances are that the grass will not recover. Thus, in this trial, steaming may have desiccated part of the grass crowns of the small plants of tall 
fescue and perennial ryegrass, causing a slower recovery of the desiccated turf compared with flaming.

Rask et al. (2012) tested whether flaming could desiccate a very resistant species such as perennial ryegrass. They found that repeated treatments at high LPG doses (above $80 \mathrm{~kg} \cdot \mathrm{ha}^{-1}$ ) resulted in the full control of perennial ryegrass. These results are in accordance with our findings. In addition, perennial ryegrass seems to be more sensitive than tall fescue to flaming because the $\mathrm{ED}_{50}$ value of perennial ryegrass was nearly $22 \%$ lower. $\mathrm{ED}_{50}$ values in Table 6 show less of a difference, thus tall fescue and perennial ryegrass may well be sensitive to steaming in a similar way.

No statistical differences were observed between the effects of high LPG and steam doses and the effect of herbicide glufosinate ammonium on hybrid bermudagrass establishment. Flaming and steaming were both as effective as the

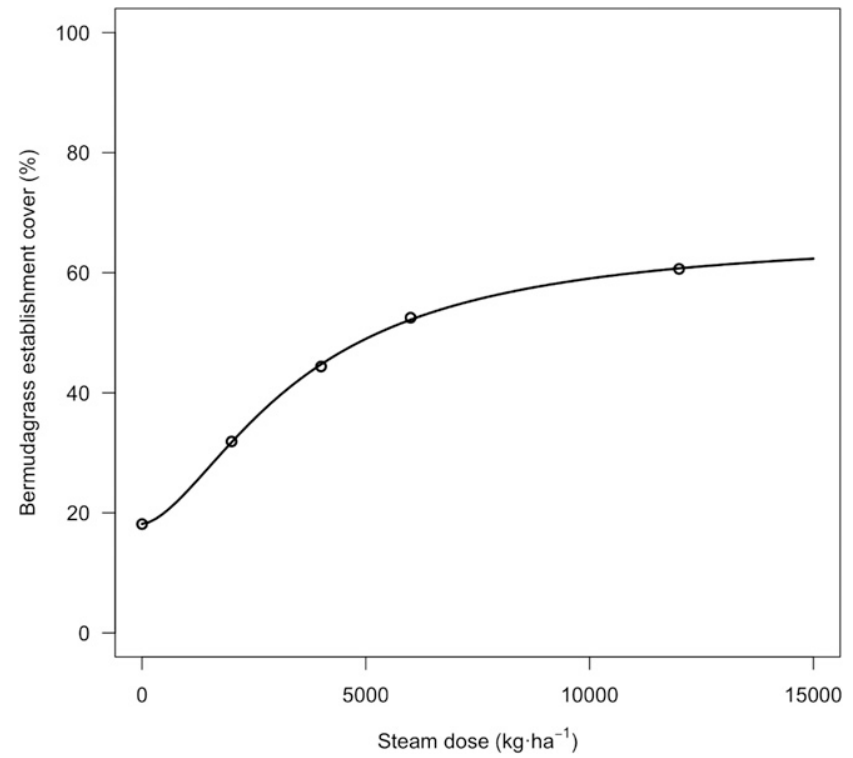

Fig. 6. Influence of preplanting steaming on hybrid bermudagrass establishment (\%) 43 weeks after planting, as affected by steam dose. The regression line is plotted using Eq. [1]. Regression parameter values $( \pm$ SE) are: $B=-1.64 \pm 1.04$, $C=18.15 \pm 4.86, D=66.44 \pm 14.26, \mathrm{ED}_{50}=3537.21 \pm 1631.50$; lack of fit test $P=0.9178 ; 1 \mathrm{~kg} \cdot \mathrm{ha}^{-1}=0.8922 \mathrm{lb} /$ acre.

herbicides in supporting hybrid bermudagrass establishment. Only low doses of LPG and steam were less effective than herbicides in hybrid bermudagrass establishment. Because the aim of the trial was to accomplish turf conversion from cool-season turfgrass to warm-season turfgrass, these results show that both flaming and steaming are a valid alternative to herbicides for turf conversion.

\section{Conclusions}

The results of this study showed that there was no statistical difference in hybrid bermudagrass establishment after flaming, steaming, or herbicide when these treatments were used to desiccate cool-season turf. Therefore, both flaming and steaming could be considered as a valid alternative to herbicides for turf conversion. These methods could contribute to eliminate or reduce the use of herbicides for those who do not wish to use herbicides. However, further research is necessary to test whether the application of flaming and steaming would give the same encouraging results in turf conversion using other cool-season and warm-season turf species. Further trials could also be carried out to try to improve the efficiency of flaming to enhance the desiccating action on cool-season turfgrass and to test the effectiveness of flaming and steaming for posttransplanting weed control on warm-season turfgrass.

Table 7. Least-square means of hybrid bermudagrass cover percentage 43 weeks after planting, as affected by pretransplanting treatment with liquified petroleum gas dose, steam dose, and comparison with herbicide.

\begin{tabular}{|c|c|c|c|c|c|}
\hline \multirow[b]{2}{*}{ Treatments } & \multirow[b]{2}{*}{ Dose $\left(\mathrm{kg} \cdot \mathrm{ha}^{-1}\right)^{\mathrm{z}}$} & \multicolumn{2}{|c|}{ Tall fescue } & \multicolumn{2}{|c|}{ Perennial ryegrass } \\
\hline & & $\begin{array}{l}\text { Logit transformed } \\
\text { LGC }^{y}(\mathrm{SE})\end{array}$ & $\begin{array}{c}\text { Back } \\
\text { transformed } \\
\text { LGC (\%) }\end{array}$ & $\begin{array}{c}\text { Logit transformed } \\
\text { LGC (SE) }\end{array}$ & $\begin{array}{c}\text { Back } \\
\text { transformed } \\
\text { LGC }(\%)\end{array}$ \\
\hline Control & 0 & $-1.70(0.434)^{*}$ & 15.5 & $-1.58(0.274)^{*}$ & 17.1 \\
\hline \multirow[t]{2}{*}{ Flaming } & 35 & $-0.81(0.434)^{\mathrm{NS}}$ & 30.8 & $-1.48(0.274)^{*}$ & 18.5 \\
\hline & 70 & $-0.19(0.434)^{\mathrm{NS}}$ & 45,4 & $-0.88(0.274)^{\mathrm{Ns}}$ & 29.3 \\
\hline \multirow[t]{4}{*}{ Steaming } & 2,000 & $-0.31(0.249)^{\mathrm{NS}}$ & 42.4 & $-1.35(0.280)^{*}$ & 20.5 \\
\hline & 4,000 & $0.26(0.249)^{\mathrm{Ns}}$ & 56.4 & $-0.75(0.280)^{\mathrm{NS}}$ & 32.1 \\
\hline & 6,000 & $0.52(0.249)^{\mathrm{Ns}}$ & 62.7 & $-0.31(0.280)^{\mathrm{NS}}$ & 42.3 \\
\hline & 12,000 & $0.85(0.249)^{\mathrm{NS}}$ & 70.0 & $0.03(0.280)^{\mathrm{NS}}$ & 50.7 \\
\hline Glufosinate ammonium & 0.75 & $0.41(0.434)$ & 60.1 & $-0.25(0.274)$ & 43.9 \\
\hline
\end{tabular}

${ }^{\mathrm{z}} 1 \mathrm{~kg} \cdot \mathrm{ha}^{-1}=0.8922 \mathrm{lb} /$ acre.

${ }^{y}$ Live green cover.

Ns, ${ }^{*}$ Not significantly or significantly different from glufosinate ammonium at $P<0.05$. 


\section{Literature cited}

Ascard, J. 1995. Effects of flame weeding on weed species at different developmental stages. Weed Res. 35:397-411.

Baldi, A., A. Lenzi, M. Nannicini, A. Pardini, and R. Tesi. 2013. Growth and nutrient content of hybrid bermudagrass grown for nursery purposes at different nitrogen, phosphorus, and potassium rates. HortTechnology 23:347-355.

Baldoin, C., I. Sartorato, D. Friso, C. De Zanche, F. De Paoli, and M. Bietresato. 2010 . Weed control by water steam using a self-propelled machine equipped with a condensation chamber. Proc. XVIIth World Congr. Intl. Commission Agr. Biosystems Eng. (CIGR). Québec City, QC, Canada. 13-17 June 2010. CSBE100427:1-10.

Bàrberi, P., A.C. Moonen, A. Peruzzi, M. Fontanelli, and M. Raffaelli. 2009. Weed suppression by soil steaming in combination with activating compounds. Weed Res. 49:55-66.

Croce, P., A. De Luca, M. Mocioni, M. Volterrani, and J.B. Beard. 2004. Adaptibility of warm-season turfgrass species and cultivars in a Mediterranean climate. Acta Hort. 661:365-368.

Del Viva, M. 2012. Erbavoglio Hi Turf: Sistema avanzato di propagazione delle macroterme. Quaderno dei Georgofili. VIII edizione. Polistampa, Florence, Italy.

Fox, J. and S. Weisberg. 2011. An R companion to applied regression. 2nd ed. Sage, Thousand Oaks, CA.

Gay, P., P. Piccarolo, D. Ricauda Aimonino, and C. Tortia. 2010a. A high efficiency steam soil disinfestation system, part I: Physical background and steam supply optimisation. Biosyst. Eng. 107:74-85.

Gay, P., P. Piccarolo, D. Ricauda Aimonino, and C. Tortia. 2010b. A high efficacy steam soil disinfestation system, part II: Design and testing. Biosyst. Eng. 107:194-201.

Hansson, D. and J. Ascard. 2002. Influence of developmental stage and time of assessment on hot water weed control. Weed Res. 42:307-316.

Hoyle, J.A., J.S. McElroy, and J.J. Rose. 2012. Weed control using an enclosed thermal heating apparatus. Weed Technol. 26:699-707.

Kerpauskas, P., A.P. Sirvydas, P. Lazauskas, R. Vasinauskiene, and A. Tamosiunas. 2006. Possibilities of weed control by water steam. Agron. Res. 4(special issue):221-225.
Knezevic, S.Z., J.C. Streibig, and C. Ritz. 2007. Utilizing R software package for dose-response studies: The concept and data analysis. Weed Technol. 21:840-848.

Kutznetsova, A., B. Brockhoff, and R.H.B. Christensen. 2015. Tests in linear mixed effects models. 5 July 2017. <https:// cran.r-project.org/web/packages/ lmerTest/index.html>.

Langshaw, E. 1995. Hot water/steam weed killing system. U.S. Patent 5385 106, Chemical Abstr. 65:2870.

Lenth, R.V. 2016. Least-squares means: The R package lsmeans. J. Stat. Softw. 69(1): 1-33.

Lulli, F., M. Volterrani, N. Grossi, R. Armeni, S. Stefanini, and L. Guglielminetti. 2012. Physiological and morphological factors influencing wear resistance and recovery in C3 and C4 turfgrass species. Funct. Plant Biol. 39:214-221.

Melander, B., N. Holst, A.C. Grundy, C. Kempenaar, M.M. Riemens, A. Verschwele, and D. Hansson. 2009. Weed occurrence on pavements in five North European towns. Weed Res. 49:516-525.

Peruzzi, A., M. Raffaelli, C. Frasconi, M. Fontanelli, and P. Bàrberi. 2012. Influence of an injection system on the effect of activated soil steaming on Brassica juncea and the natural weed seedbank. Weed Res. 52:140-152.

Peruzzi, A., M. Raffaelli, M. Ginanni, M. Fontanelli, and C. Frasconi. 2011. An innovative self-propelled machine for soil disinfection using steam and chemicals in an exothermic reaction. Biosyst. Eng. 110:434-442.

R Core Team. 2016. R: A language and environment for statistical computing. 21 Mar. 2016. <https://www.R-project. org $>$.

Raffaelli, M., C. Frasconi, M. Fontanelli, L. Martelloni, and A. Peruzzi. 2015. LPG burners for weed control. Appl. Eng. Agr. 31:717-731.

Raffaelli, M., L. Martelloni, C. Frasconi, M. Fontanelli, S. Carlesi, and A. Peruzzi. 2016. A prototype band-steaming machine: Design and field application. Biosyst. Eng. 144:61-71.

Raffaelli, M., L. Martelloni, C. Frasconi, M. Fontanelli, and A. Peruzzi. 2013. Development of machines for flaming weed control on hard surfaces. Appl. Eng. Agr. 29:663-673.

Rask, A.M., C. Andreasen, and P. Kristoffersen. 2012. Response of Lolium perenne to repeated flame treatments with various doses of propane. Weed Res. 52:131-139.

Rask, A.M. and P. Kristoffersen. 2007. A review of non-chemical weed control on hard surfaces. Weed Res. 47:370-380.

Rasmussen, J., M. Nørremark, and B.M. Bibby. 2007. Assessment of leaf cover and crop soil cover in weed harrowing research using digital images. Weed Res. 47:299-310.

Ritz, C., F. Baty, J.C. Streibig, and D. Gerhard. 2015. Dose-response analysis using R. PLoS One 10:e0146021.

Sartorato, I., G. Zanin, C. Baldoin, and C. De Zanche. 2006. Observations on the potential of microwaves for weed control. Weed Res. 46:1-9.

Seefeldt, S.S., J.E. Jensen, and E.P. Fuerst. 1995. Log-logistic analysis of herbicide dose-response relationships. Weed Technol. 9:218-227.

Syrvidas, A., P. Lazauskas, R. Vasinauskieneì, and P. Kerpauskas. 2002. Thermal weed control by water steam. Proc. 5th European Weed Res. Soc. Wkshp. Physical Weed Control. Pisa, Italy. 11-13 Mar. 2002. p. 253-262.

Turgeon, A.J. 2012. Turfgrass management. 9th ed. Prentice Hall, Upper Saddle River, NJ.

Ulloa, S.M., A. Datta, and S.Z. Knezevic. 2010a. Growth stage influenced differential response of foxtail and pigweed species to broadcast flaming. Weed Technol. 24:319-325.

Ulloa, S.M., A. Datta, and S.Z. Knezevic. $2010 \mathrm{~b}$. Tolerance of selected weed species to broadcast flaming at different growth stages. Crop Prot. 29:1381-1388.

Volterrani, M. and C. De Bertoldi. 2012. I generi di macroterme per i tappeti erbosi nel bacino del Mediterraneo: Cynodon, Paspalum e Zoysia. Quaderno dei Georgofili, VIII edizione, Polistampa, Florence, Italy.

Volterrani, M., N. Grossi, F. Lulli, and M. Gaetani. 2008. Establishment of warmseason turfgrass species by transplant of single potted plants. Acta Hort. 783:7784.

Wheeler, M.W., R.M. Park, and A.J. Bailer. 2005. Comparing median lethal concentration values using confidence interval overlap or ratio test. Environ. Toxicol. Chem. 25:1441-1444. 